\title{
Miliaria crystallina: relevance in patients with hemato-oncological febrile neutropenia
}

\author{
Uday Yanamandra, ${ }^{1,2}$ Alka Khadwal, ${ }^{2}$ Pankaj Malhotra, ${ }^{2}$ Subhash Varma ${ }^{2}$
}

${ }^{1}$ Deaprtment of Internal Medicine, Armed Forces Medical College, Pune, Maharashtra, India ${ }^{2}$ Department of Hematology, Internal Medicine, Post Graduate Institute of Medical Education and Research, Chandigarh, India

\section{Correspondence to}

Dr Uday Yanamandra, udayj2@gmail.com

Accepted 11 November 2015
CrossMark

To cite: Yanamandra $U$, Khadwal A, Malhotra P, et al. BMJ Case Rep Published online: [please include Day Month Year] doi:10.1136/bcr-2015212231

\section{DESCRIPTION}

We present two cases of febrile neutropenia (FN) with miliaria crystallina. The first patient, a 33-year-old man with pre-B acute lymphoid leukaemia (ALL) was admitted for $\mathrm{FN}$ postconsolidation with high-dose methotrexate (ANC-282/ $\mu \mathrm{L}$ ) on empirical antibiotics. He developed a clear fluidfilled vesicular rash appearing as water droplets (figure 1) following high-grade fever $\left(104^{\circ} \mathrm{F}\right)$. The second patient, an 18-year-old man, also a case of ALL, was admitted with bronchopneumonia, diarrhoea and FN (ANC-184/ $\mu$ L) with hypernatremia following induction chemotherapy (BFM-90 protocol). He developed sand crystal-like lesions over the face and upper chest subsequent to fever of $105^{\circ} \mathrm{F}$ (figure 2). Tzank/fungal/bacterial smears from the lesions were normal in both patients. Skin lesions were diagnosed as miliaria crystallina. These lesions resolved within $72 \mathrm{~h}$ of subsidence of fever, with supportive therapy.

Miliaria crystallina is a self-limiting eccrine gland disorder due to blockage of sweat glands presenting as fluid-filled vesicles that easily break. ${ }^{1}$ It occurs mostly in tropical regions secondary to heat and humidity, and is predisposed by high-grade fever, hypernatremia and neutropenia. ${ }^{2}$ Biopsy is unnecessary, as the characteristic rash is selfdefining. Patients are asymptomatic and lesions resolve spontaneously by keeping the affected area cool and dry. ${ }^{3}$

The differential for fever and rash in a patient with neutropenia is broad and requires an extensive microbiological/radiological work up given the high

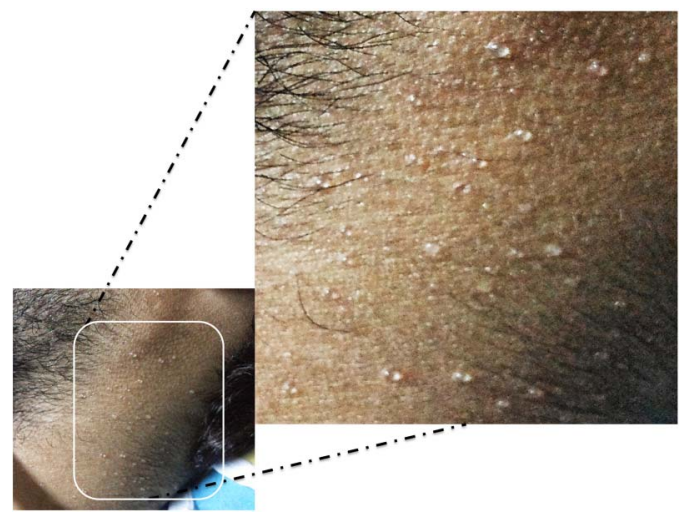

Figure 1 Miliaria crystallina (appearing as water droplets) on the neck.

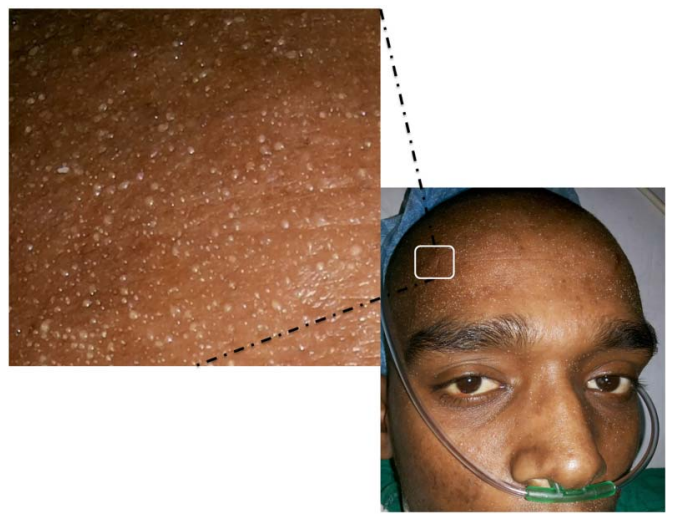

Figure 2 Sand crystal-like rash of miliaria crystallina over the forehead.

morbidity and mortality. Evaluation of skin may therefore provide a quicker diagnosis. We present this case to emphasise that miliaria crystallina is a benign self-remitting disorder that does not warrant extensive evaluation/high doses of antibiotics.

\section{Learning points}

- Early diagnosis of this common entity in hemato-oncological patients in the tropics can avoid unnecessary investigations and therapy.

- Lesions resolve with mere supportive care, such as controlling the room temperature, and keeping the affected area cool and dry.

Contributors All the authors were actively involved in managing the cases. UY and AK prepared the manuscript.

Competing interests None declared.

Patient consent Obtained.

Provenance and peer review Not commissioned; externally pee reviewed.

\section{REFERENCES}

1 Wenzel FG, Horn TD. Nonneoplastic disorders of the eccrine sweat glands. J Am Acad Dermatol 1998;38:1-17.

2 Haas N, Martens F, Henz BM. Miliaria crystallina in an intensive care setting. Clin Exp Dermatol 2004:29:32-4.

3 Nguyen TA, Ortega-Loayza AG, Stevens MP. Miliaria-rash after neutropenic fever and induction chemotherapy for acute myelogenous leukemia. An Bras Dermatol 2011;86(4 Suppl 1): S104-6. 
Copyright 2015 BMJ Publishing Group. All rights reserved. For permission to reuse any of this content visit http://group.bmj.com/group/rights-licensing/permissions.

BMJ Case Report Fellows may re-use this article for personal use and teaching without any further permission.

Become a Fellow of BMJ Case Reports today and you can:

- Submit as many cases as you like

- Enjoy fast sympathetic peer review and rapid publication of accepted articles

- Access all the published articles

- Re-use any of the published material for personal use and teaching without further permission

For information on Institutional Fellowships contact consortiasales@bmjgroup.com

Visit casereports.bmj.com for more articles like this and to become a Fellow 